\title{
Culture and Religion in International Relations
}

Series Editors:

Yosef Lapid and Friedrich Kratochwil

\section{Published by Palgrave Macmillan:}

Dialogue Among Civilizations: Some Exemplary Voices

By Fred Dallmayr

Religion in International Relations: The Return from Exile

Edited by Fabio Petito and Pavlos Hatzopoulos

Identity and Global Politics: Theoretical and Empirical Elaborations

Edited by Patricia M. Goff and Kevin C. Dunn

Reason, Culture, Religion: The Metaphysics of World Politics

By Ralph Pettman

Bringing Religion into International Relations

By Jonathan Fox and Shmuel Sandler

The Global Resurgence of Religion and the Transformation of International Relations:

The Struggle for the Soul of the Twenty-First Century

By Scott M. Thomas

Religion, Social Practice, and Contested Hegemonies: Reconstructing the Public Sphere in Muslim Majority Societies

Edited by Armando Salvatore and Mark LeVine

Beyond Eurocentrism and Anarchy: Memories of International Order and Institutions By Siba N. Grovogui

The Public Sphere: Between Tradition and Modernity

By Armando Salvatore

Civilizational Identity: The Production and Reproduction of 'Civilizations' in International Relations

Edited by Martin Hall and Patrick Thaddeus Jackson

Civilizing Missions: International Religious Agencies in China

By Miwa Hirono

Civilizational Dialogue and World Order: The Other Politics of Cultures,

Religions, and Civilizations in International Relations

Edited by Michális S. Michael and Fabio Petito 
Why the West Fears Islam: An Exploration of Muslims in Liberal Democracies By Jocelyne Cesari

Towards a Postsecular International Politics: New Forms of Community, Identity, and Power

Edited by Luca Mavelli and Fabio Petito 


\section{TOWARDS A POSTSECULAR InTERnATIONAL POLITICS}

New Forms of Community, IDENTITY, AND POWER

Edited by

Luca Mavelli and Fabio Petito 
TOWARDS A POSTSECULAR INTERNATIONAL POLITICS

Copyright (C) Luca Mavelli and Fabio Petito, 2014.

Softcover reprint of the hardcover 1st edition 2014 978-1-137-34177-8 All rights reserved.

First published in 2014 by

PALGRAVE MACMILLAN ${ }^{\circledR}$

in the United States-a division of St. Martin's Press LLC,

175 Fifth Avenue, New York, NY 10010.

Where this book is distributed in the UK, Europe and the rest of the world, this is by Palgrave Macmillan, a division of Macmillan Publishers Limited, registered in England, company number 785998, of Houndmills, Basingstoke, Hampshire RG21 6XS.

Palgrave Macmillan is the global academic imprint of the above companies and has companies and representatives throughout the world.

Palgrave ${ }^{\circledR}$ and Macmillan ${ }^{\circledR}$ are registered trademarks in the United States, the United Kingdom, Europe and other countries.

ISBN 978-1-349-46518-7

DOI $10.1057 / 9781137341785$

ISBN 978-1-137-34178-5 (eBook)

Library of Congress Cataloging-in-Publication Data

Towards a postsecular international politics : new forms of community, identity, and power / edited by Luca Mavelli and Fabio Petito.

pages $\mathrm{cm}$

Includes index.

1. Religion and international relations. 2. Postsecularism—Political aspects. 3. World politics-21st century. I. Mavelli, Luca, editor of compilation. II. Petito, Fabio, editor of compilation.

BL65.155T678 2014

$327.101-\mathrm{dc} 23$

2014006881

A catalogue record of the book is available from the British Library.

Design by Newgen Knowledge Works (P) Ltd., Chennai, India.

First edition: August 2014

109876554321 
To Anaïs, Elisa, Gabriel, and Foseph 
This page intentionally left blank 
I Towards a Postsecular International Politics

Luca Mavelli and Fabio Petito

\section{Part I Theories}

2 Achieving Political Legitimacy in the Twenty-First Century: Secular and Postsecular Imperatives Richard Falk

3 Trauma and Dislocation in the Postsecular World: Religious Fervor and the Problem of Methodology Stephen Chan

4 A Postsecular Global Order: Metaphysical Not Political? Nicholas Rengger

5 The Golden Rule on the Green Stick: Leo Tolstoy's International Thought for a "Postsecular" Age Alexandre Christoyannopoulos

\section{Part II Cases}

6 Postsecularity and the Contending Visions of the European Political Imagination in International Relations

Scott M. Thomas and Anthony O'Mahony

7 The Clash of Postsecular Orders in Contemporary Russia Richard Sakwa

8 The Politics of Postsecular Borders: Everyday Life and the Ground Zero Mosque Controversy Stacey Gutkoreski 
viii Contents

9 Secularism, Postsecularism, and States of Exception in the 20II Egyptian Revolution and Its Aftermath

Luca Mavelli

\section{Part III Actors}

Io Faith-Based Organizations at the European Union and United Nations: From Marginalization to Significance Feffrey Haynes

II Faith-Based Organizations and Postsecularism in Contemporary International Relations

Erin K. Wilson

I2 Postsecularism, Islam, and Religious Freedom:

Cases from the European Court of Human Rights

Turan Kayaoğlu

List of Contributors

Index 


\section{ACKNOWLEDGMENTS}

The contributions collected in this volume were first presented at "The Postsecular in International Politics," an international

1 ESRC-sponsored conference at the University of Sussex held in October 20II. This event was made possible by the generous support of the Economic and Social Research Council (Fellowship Grant PTA-026-27-2645) and the Department of International Relations at the University of Sussex (a particular thanks goes to the then Head of Department, Stefan Elbe), both of which are gratefully acknowledged. The two intense days of presentations, discussions, questions, and conversations, which would have not run as smoothly as they did without the superb organizational help of Joanna Wood, were an exceptional opportunity to delve into the intricacies and complexities of the postsecular in international politics. Therefore, our first thanks goes to all those who took part and contributed to this event, which include our authors plus Mariano Barbato, Pınar Bilgin, Joe Camilleri, Antonio Cerella, Fred Dallmayr, Hilal Elver, İstar Gözaydın, Cesare Merlini, Adrian Pabst, Mustapha Pasha, Huw Rees, Niamh Reilly, Olivier Roy, and Kees Van Der Pijl-some of whose contributions have appeared in the 2012 Special Issue of the Review of International Studies "The Postsecular in International Relations" (vol. 38, no. 5). Our second thanks goes to our authors for their patience, commitment to the project, and capacity to cope with our numerous emails setting deadlines and suggesting revisions. Finally, a special thanks goes to Yosef Lapid and Friedrich Kratochwil for their keen interest in this project and for welcoming it into their series, and to Farideh Koohi-Kamali and Sara Doskow for their help in bringing this book to publication.

LuCa Mavelli

Fabio Petito

February 5, 20I4 